\title{
Effect of Five Types Inert Dust to Rhyzopertha dominica (Fabricius) (Coleoptera: Bostrichidae) in Stored Rice Seeds
}

\author{
Ludji Pantja Astuti ${ }^{*}$, Rohmatin Maula, Akhmad Rizali, Muhammad Bayu Mario \\ Department of Plant Pests and Diseases, Faculty of Agriculture, University of Brawijaya, Malang, Indonesia
}

\begin{abstract}
Rhyzopertha dominica (F.) is one of the primary pests in stored rice. Generally, pest control in the storage was done by spraying and fumigation using synthetic insecticide. The application of chemical insecticide using phosphine can cause resistant to insect pests and toxic to humans. Regarding the negative effect of insecticide application, the alternative control by using natural resources like inert dust is expected to be a good solution to control pests of stored products. This research was aimed to study the effectiveness of five inert dusts, which are: rice husks ash, volcanic ash, giant bamboo leaves ash, corncobs ash, coconut shells ash to adult mortality and the inhibition of population growth of $R$. dominica on stored rice seeds. The results showed that giant bamboo leaves at $8 \mathrm{~g} \mathrm{~kg}^{-1}$ caused $100 \%$ of mortality and faster than other inert dusts tested. Giant bamboo leaves and rice husks were more effective to suppress the number of eggs, larvae, pupae, and new adults (F1). Inert dust could decrease the hatchability of eggs, inhibit population growth, and decrease the weight of new adults (F1). The damage to the treated rice seeds was significantly lower than untreated rice seeds.
\end{abstract}

Keywords: ash, control, inert dust, silica, stored product pest

\section{INTRODUCTION}

Lesser grain borer, Rhyzopertha dominica (F.) (Coleoptera: Bostrichidae) is the primary pest in stored rice, tobacco, beans, cacao bean, biscuits, and some dried fruits [1,2]. Infestation of pest stored product can cause losses from $5-10 \%$ of total global production, while the losses in tropical and subtropical countries could reach up to $50 \%$ [3]. The destructive phase is on larvae and adult. Larvae feed on the embryonic and endosperm of seed, and it cause the ungerminated seed, while adult feed on the surface layer of the seed irregularly [4].

Pest control in the storage nowadays is based on insecticide by spraying and fumigation using carbon monoxide gas (CO). Fumigation technique can only applied on the sealed storage [5]. Various types of insecticides which occasionally used in the storage are organophosphate and carbamates for spraying, while phosphine for fumigation [6,7]. Misuse of organophosphate can cause poisoning and death [8-11]. Furthermore, using phosphine at high dose and unwise application can cause pest resistant.

Inert dust application is one of the alternative control that can be easily adopted by farmers. Inert dust application as grain protectant has been used since the Aztecs of ancient Mexico

\footnotetext{
* Correspondence Address:

Ludji Pantja Astuti

E-mail : ludji_pa@ub.ac.id

Address : Dept. Plant Pests and Diseases, University of Brawijaya, Malang 65145.
}

which used mixed lime and corn to protect their seeds. However, this materials could not be commercialize anymore in the last fifty years [12]. The mechanisms of inert dust to insect body is by removing the body fluid of insect and eroding the integument, this condition cause an excessive evaporation on its body and eventually cause death [13]. Silica $\left(\mathrm{SiO}_{2}\right)$ content in inert dust material can cause insect death because of the fat layer on cuticles is absorbed by silica reaction. Several materials that have high silica content and easy to find in Indonesia are volcanic ash $(45.70 \%)$, rice husks $(79 \%)$, giant bamboo leaves $(58.30 \%)$, corncobs $(47.78 \%)$, and coconut shells (45.05\%) [14-18]. This research was aimed to study the effectiveness of five types of ash as an inert dust materials i.e. volcanic ash, rice husks, giant bamboo leaves, corncobs, and coconut shells to adult mortality and the inhibition of population growth of $R$. dominica on stored rice seeds.

\section{METHOD}

The research was conducted at Plant Pest Laboratory, Department of Plant Pests and Diseases, Faculty of Agriculture, University of Brawijaya.

\section{Insect Diet}

Brown rice Ciherang variety was used for $R$. dominica rearing and White rice seed Ciherang variety was used in the experiment. These materials were removed from debris i.e. rocks, husks, damage seeds, and insect infestation. Cold 
sterilization process was done for both materials $[19,20]$. These materials was put into a glass tube $(\varnothing=13 \mathrm{~cm} ; \mathrm{h}=25 \mathrm{~cm})$ during the sterilization process in the freezer at $-15^{\circ} \mathrm{C}$ for seven days then removed to refrigerator at $5^{\circ} \mathrm{C}$ for seven days and removed to the laboratory room $\left(27 \pm 2^{\circ} \mathrm{C} ; 65 \% \mathrm{RH}\right)$ for fourteen days.

\section{Insect Rearing}

The $R$. dominica was obtained from Assessment Institute for Agricultural Technology, Karangploso, Malang. Insect rearing was done by infest 200 adults insect into $500 \mathrm{~g}$ of brown rice for seven days in the glass tube $(\varnothing=14.5 \mathrm{~cm}$; $\mathrm{h}=$ $16 \mathrm{~cm}$ ) and covered by gauze materials for air circulation [19]. After seven days infestation, adult infestation were removed and the feed was incubated until F1 progeny emerged as the treated insect. Adults sexes was distinguish by the colour of abdominal segments [19].

\section{Inert Dust Preparation}

Five types of ash as inert dust materials that used in this research were from Bromo mountain volcanic ash, rice husks, corncobs, giant bamboo leaves, and coconut shells. All materials were dried and burned separately. Ashes were sieved using $53 \mu \mathrm{m}$ and dried in the oven at $60^{\circ} \mathrm{C}$ for one hour to reduce the water content [21]. Two levels of dose were used in this research, i.e. 4 and $8 \mathrm{~g} \mathrm{~kg}^{-1}$ of rice seed.

\section{Inert Dust Content Analysis}

This analysis was carried out in Central Laboratory, Faculty of Mathematics and Natural Sciences, State University of Malang. Analysis of silica level was done by X-ray Fluorescent (XRF) technique to determine the content of chemical composition on five type's inert dust, i.e. rice husks ash, volcanic ash, giant bamboo leaves ash, corncobs ash, and coconut shells ash.

\section{Adult Mortality}

Glass tube $(\varnothing=6 \mathrm{~cm} ; \mathrm{h}=12 \mathrm{~cm})$ contained of $100 \mathrm{~g}$ of rice seeds was mixed by each dose of five types inert dust regarding the treatment. Rice seeds and inert dust were mixed manually for two minutes [22]. 25 paired of adults (7-14 days old) were infested to the glass tube. Adults mortality was observed on 1, 3, 7, and 10 days after infestation (DAI) [23] and calculated by this formula [24]:

Adult mortality $(\%)=\frac{\text { Number of dead adults }}{\text { Number of adults infestation }} \times 100 \%$

If there were dead adults in the control, the adult mortality was corrected using this formula [25]:

$$
\text { Corrected mortality }(\%)=\left(\frac{X-Y}{X}\right) 100 \%
$$

Where, $X$ : number of live adults in control

$$
Y \text { : number of live adults in treatment }
$$

\section{Insect Population Growth}

Total of 600 rice seeds mixed with each inert dust types and two dose levels regarding the treatment in each glass tube $(\varnothing=4 \mathrm{~cm} ; \mathrm{h}=6.5$ $\mathrm{cm})$. Number of eggs, larvae, and pupae were calculated on 10, 29, and 35 DAl. The eggs were observed by looking the presence of oviposition site on the rice seeds surface. Larvae and pupae were observed by destructive method, while adults were observed daily from the first day of progeny emerged (F1) until all F1 emerged before F2 generation appeared [26,27]. F1 weight was also calculated as the observed variables.

\section{Seed Damage}

The seed damage was determined by seed germination test without cleaning the inert dust. 100 seeds was randomly sampled and germinated on plastic trays $(33 \times 23 \mathrm{~cm})$. The seeds were observed after 7 days germinated [28]. Un-germinated seeds in 7 days were classified as damaged seed. The percentage of seed damage was calculated by this formula [29]:

$$
\text { Seed damage }(\%)=\frac{\text { Number of damaged seeds }}{100} \times 100 \%
$$

\section{RESULTS AND DISCUSSION}

\section{Adult mortality}

Application of five types inert dust on rice seeds was significantly affect the adult mortality of $R$. dominica on $1 \mathrm{DAl}\left(\mathrm{F}_{10,32}=159.04 ; \mathrm{P}<0.0001\right)$, 3 DAl $\left(F_{10,32}=69.001 ; P<0.0001\right), 7$ DAl $\left(F_{10,32}=\right.$ 524.974; $P<0.0001)$, and $10 \mathrm{DAl}\left(\mathrm{F}_{10,32}=844.786\right.$; $\mathrm{P}<0.0001)$. Adult mortality on giant bamboo leaves ash at $8 \mathrm{~g} \mathrm{~kg}^{-1}$ dose was significantly higher than other treatments (99.33\%) on 1 DAl. Giant bamboo leaves ash at 4 and $8 \mathrm{~g} \mathrm{~kg}^{-1}$ caused total death of adults on 3 DAl and was significantly higher of adult mortality than other treatments. As well as on rice husk ash on 7 DAl at both doses caused total death of adults and was significantly different with other treatments (Table 1).

The death of insect was happened because when the insect body passed through the grain layer, inert dust particles attached on the insect cuticle. Silica content on inert dust would react with insect body and caused the desiccation on wax layer of the cuticle, thus water content loss from their bodies [30]. According to analysis of silica content $\left(\mathrm{SiO}_{2}\right)$ by XRF method was relatively higher in rice husks ash (77.7\%) and giant 
bamboo leaves (51\%) compared to volcanic ash (39.3\%), corncobs ash (29.3\%) and coconut shells ash (25\%). Correlation analysis results revealed that silica content was positively correlated with adult mortality ( $r=0.788 ; P=0.007)$. Longer duration exposure of inert dust could increase adult mortality. This was in line with the previous research on Sitophilus zeamais Motsch. (Coleoptera: Curculionidae) which showed that adult mortality was increase followed by the exposure time of inert dust application [31]. Athanassiou et al. also stated that the exposure time was crucial for effective application of diatomaceous earth materials because it was related to the insect movement [32].

\section{Insect Population Growth}

Application of five types inert dust on rice seed was significantly reduce the insect population growth of $R$. dominica on different life stages, i.e. number of eggs $\left(F_{10,32}=34.36\right.$; $P<0.0001)$, larvae $\left(F_{10,32}=36.48 ; P<0.0001\right)$, pupae $\left(F_{10,32}=37.43 ; P<0.0001\right)$, and new adults $\left(F_{10,32}=\right.$ 36.64; $\mathrm{P}<0.0001)$. The number of eggs, larvae, pupae, and new adults in giant bamboo leaves ash at both doses was significantly lower than other treatments and was not significantly different with rice husks ash at both doses. The new adults were not emerged on the giant bamboo leaves ash and rice husks ash treatment at both doses (Table 2).

Number of eggs on giant bamboo leaves ash and rice husks ash were lower because there had higher mortality than other treatments. The speed of inert dust causing adult mortality was affected on the number of eggs laid. The faster of adult mortality, the more of eggs laid [33]. Eggs hatchability to larvae on treated seeds were lower than control because the eggs which laid on the outer surface of grain was directly contact with inert dust. Previous research also mentioned that eggs hatchability of Tribolium castaneum (Herbst), Tenebroides mauritanicus L. (Coleoptera: Tenebrionidae), Oryzaephilus surinamensis (L.) (Coleoptera: Silvanidae), $R$. dominica and Callosobruchus chinensis (L.) (Coleoptera: Chrysomelidae) was lower when the eggs were exposed by diatomaceous earth [33]. The most effective period to apply inert dust was on the stages which directly exposed by inert dust, particularly on newly hatched larvae [33]. Moreover, application of diatomaceous earth can reduce the insect offspring by increasing adults mortality and decreasing oviposition [34].

Table 1. Adult mortality on treated rice seeds by five types of inert dust

\begin{tabular}{|c|c|c|c|c|c|c|}
\hline \multirow{2}{*}{ Treatment (Ash) } & \multicolumn{6}{|c|}{ Adult mortality (\%)* } \\
\hline & 1 DAI & 3 DAI & & 7 DAI & $10 \mathrm{DAl}$ & \\
\hline Untreated (Control) & $0.00 \pm 0.00 \mathrm{a}$ & $0.00 \pm 0.00$ & a & $0.00 \pm 0.00 \mathrm{a}$ & $0.00 \pm 0.00$ & a \\
\hline Rice husks $4 \mathrm{~g} \mathrm{~kg}^{-1}$ & $71.33 \pm 5.03 \mathrm{c}$ & $88.00 \pm 5.29$ & e & $100.0 \pm 0.00 \mathrm{e}$ & $100.0 \pm 0.00$ & f \\
\hline Rice husks $8 \mathrm{~g} \mathrm{~kg}^{-1}$ & $74.00 \pm 6.00 \mathrm{c}$ & $90.00 \pm 5.29$ & e & $100.0 \pm 0.00 \mathrm{e}$ & $100.0 \pm 0.00$ & $f$ \\
\hline Volcanic $4 \mathrm{~g} \mathrm{~kg}^{-1}$ & $2.00 \pm 2.00 \mathrm{ab}$ & $10.00 \pm 5.29$ & $\mathrm{~b}$ & $47.67 \pm 4.06 \mathrm{~b}$ & $62.67 \pm 5.05$ & b \\
\hline Volcanic $8 \mathrm{~g} \mathrm{~kg}^{-1}$ & $4.00 \pm 4.00 \mathrm{~b}$ & $18.00 \pm 12.35$ & bc & $59.67 \pm 0.71 \mathrm{c}$ & $67.00 \pm 3.00$ & b \\
\hline Giant bamboo leaves $4 \mathrm{~g} \mathrm{~kg}^{-1}$ & $88.00 \pm 5.29 \mathrm{c}$ & $100.0 \pm 3.08$ & f & $100.0 \pm 0.00 \mathrm{e}$ & $100.0 \pm 0.00$ & $f$ \\
\hline Giant bamboo leaves $8 \mathrm{~g} \mathrm{~kg}^{-1}$ & $93.33 \pm 4.64 \mathrm{~d}$ & $100.0 \pm 3.46$ & $f$ & $100.0 \pm 0.00 \mathrm{e}$ & $100.0 \pm 0.00$ & $f$ \\
\hline Corncobs $4 \mathrm{~g} \mathrm{~kg}^{-1}$ & $2.00 \pm 2.00 \mathrm{ab}$ & $21.33 \pm 11.73$ & bc & $63.67 \pm 4.95 \mathrm{~cd}$ & $79.00 \pm 1.73$ & $\mathrm{de}$ \\
\hline Corncobs $8 \mathrm{~g} \mathrm{~kg}^{-1}$ & $3.33 \pm 4.16 \quad b$ & $21.33 \pm 16.17$ & bc & $68.67 \pm 7.38 \mathrm{~d}$ & $72.33 \pm 3.00$ & c \\
\hline Coconut shells $4 \mathrm{~g} \mathrm{~kg}^{-1}$ & $0.00 \pm 0.00 a$ & $24.67 \pm 11.55$ & $\mathrm{~cd}$ & $61.67 \pm 4.74 \mathrm{c}$ & $80.33 \pm 4.06$ & e \\
\hline Coconut shells $8 \mathrm{~g} \mathrm{~kg}^{-1}$ & $2.00 \pm 2.31 \mathrm{~b}$ & $40.00 \pm 16.00$ & $\mathrm{~d}$ & $61.67 \pm 3.54 \mathrm{c}$ & $79.00 \pm 2.65$ & de \\
\hline
\end{tabular}

Notes: * Mean \pm SD followed by different letters in the same column are significantly different by Duncan's Multiple Range Test $(\alpha<0.05)$. Data are transformed by Arcsin. DAl: day after infestation.

Table 2. Number of eggs, larvae, pupae, and new adults on treated rice seeds by five types of inert dust

\begin{tabular}{|c|c|c|c|c|}
\hline Treatment & No. of eggs* & No. of larvae* & No. of pupae* & No. of new adults* \\
\hline Untreated (Control) & $142.00 \pm 20.46 \mathrm{~d}$ & $122.22 \pm 34.65 \mathrm{c}$ & $117.78 \pm 30.96 \mathrm{~d}$ & $91.11 \pm 17.03 \mathrm{~d}$ \\
\hline Rice husks $4 \mathrm{~g} \mathrm{~kg}^{-1}$ & $26.67 \pm 6.50$ a & $13.33 \pm 6.50 \mathrm{a}$ & $4.44 \pm 3.69$ a & $0.00 \pm 0.00 \mathrm{a}$ \\
\hline Rice husks $8 \mathrm{~g} \mathrm{~kg}^{-1}$ & $20.00 \pm 7.00 \mathrm{a}$ & $4.44 \pm 6.85 a$ & $2.22 \pm 3.69$ a & $0.00 \pm 0.00 \mathrm{a}$ \\
\hline Volcanic $4 \mathrm{~g} \mathrm{~kg}^{-1}$ & $71.11 \pm 10.15 \mathrm{c}$ & $51.11 \pm 10.15 b$ & $40.00 \pm 7.00 \mathrm{c}$ & $33.33 \pm 6.51 \mathrm{c}$ \\
\hline Volcanic $8 \mathrm{~g} \mathrm{~kg}^{-1}$ & $60.00 \pm 7.00 \mathrm{bc}$ & $33.33 \pm 07.00 \mathrm{~b}$ & $33.33 \pm 11.55$ bc & $26.67 \pm 13.50 \mathrm{bc}$ \\
\hline Giant bamboo leaves $4 \mathrm{~g} \mathrm{~kg}^{-1}$ & $20.00 \pm 7.00 \mathrm{a}$ & $0.00 \pm 0.00 \mathrm{a}$ & $0.00 \pm 0.00$ a & $0.00 \pm 0.00 \mathrm{a}$ \\
\hline Giant bamboo leaves $8 \mathrm{~g} \mathrm{~kg}^{-1}$ & $15.56 \pm 4.04 a$ & $0.00 \pm 0.00 \mathrm{a}$ & $0.00 \pm 0.00 a$ & $0.00 \pm 0.00 \mathrm{a}$ \\
\hline Corncobs $4 \mathrm{~g} \mathrm{~kg}^{-1}$ & $48.89 \pm 10.15 b$ & $35.56 \pm 10.26 b$ & $26.67 \pm 6.51 b$ & $17.78 \pm 8.08 \mathrm{~b}$ \\
\hline Corncobs $8 \mathrm{~g} \mathrm{~kg}^{-1}$ & $55.55 \pm 10.26$ bc & $37.78 \pm 6.51 b$ & $28.89 \pm 3.46 b$ & $20.00 \pm 7.00 \mathrm{bc}$ \\
\hline Coconut shells $4 \mathrm{~g} \mathrm{~kg}^{-1}$ & $62.22 \pm 4.04$ bc & $33.33 \pm 6.51 \mathrm{~b}$ & $26.67 \pm 6.51 b$ & $20.00 \pm 7.00 \mathrm{bc}$ \\
\hline Coconut shells $8 \mathrm{~g} \mathrm{~kg}^{-1}$ & $62.22 \pm 8.08$ bc & $40.00 \pm 13.00 \mathrm{~b}$ & $31.11 \pm 10.15$ bc & $22.22 \pm 8.08$ bc \\
\hline
\end{tabular}

Notes: *Mean \pm SD values followed by different letters in the same column are significantly different by Duncan's Multiple Range Test $(\alpha<0.05)$. Data are transformed by square root. 
Table 3. New adults (F1) weight on treated rice seeds by five types of inert dust

\begin{tabular}{lrl}
\hline Treatment & New adults weight (mg/adult)* \\
\hline Untreated (Control) & $1.23 \pm 0.07 \mathrm{D}$ \\
Rice husks $4 \mathrm{~g} \mathrm{~kg}^{-1}$ & - \\
Rice husks $8 \mathrm{~g} \mathrm{~kg}^{-1}$ & - \\
Volcanic $4 \mathrm{~g} \mathrm{~kg}^{-1}$ & $1.12 \pm 0.06 \quad \mathrm{abc}$ \\
Volcanic $8 \mathrm{~g} \mathrm{~kg}^{-1}$ & $1.06 \pm 0.02 \mathrm{C}$ \\
Giant bamboo leaves $4 \mathrm{~g} \mathrm{~kg}^{-1}$ & - & - \\
Giant bamboo leaves $8 \mathrm{~g} \mathrm{~kg}^{-1}$ & $1.06 \pm 0.05 \mathrm{abc}$ \\
Corncobs $4 \mathrm{~g} \mathrm{~kg}^{-1}$ & $1.02 \pm 0.09 \mathrm{~A}$ \\
Corncobs $8 \mathrm{~g} \mathrm{~kg}^{-1}$ & $1.04 \pm 0.10 \mathrm{Ab}$ \\
Coconut shells $4 \mathrm{~g} \mathrm{~kg}^{-1}$ & $1.09 \pm 0.07 \mathrm{Bc}$ \\
Coconut shells $8 \mathrm{~g} \mathrm{~kg}^{-1}$ & & \\
\hline
\end{tabular}

Notes: *Means \pm SD followed by different letters in the same column are significantly different by Duncan's Multiple Range Test $(\alpha<0.05)$. Data are transformed by square root.

The weight of new adults (F1) on treated seeds (volcanic ash, corncobs ash, coconut shells ash) were significantly reduce than control $\left(F_{6,20}=\right.$ 15.31; $P<0.0001)$ (Table 3). This was happened because of the silica content was able to reduce the cuticle function of insect body. Rice seeds were harder due to inert dust mechanism by adsorbing the water content of seed. Therefore, insect feeding activity was disrupted and caused smaller and lighter on F1 weight.

Hygroscopic silica was able to reduce the moisture content of insect body which cause weight decreased due to the fluid loss from its body [35]. Alexander et al. also explained that inert dust application can reduce $30 \%$ of Sitophilus granarius L. adult weight [36]. Moreover, the desiccation of insect body cause water loss and the insect will be died if they lose $60 \%$ of body fluids or $30 \%$ of body weight [37].

\section{Seed Damage}

Application of five types inert dust on rice seeds was significantly reduce the percentage of seed damage by $R$. dominica than control $\left(F_{10,32}=\right.$ 35.39; $P<0.0001)$. The percentage of seed damage on giant bamboo leaves ash at $8 \mathrm{~g} \mathrm{~kg}^{-1}$ was not significantly different at $4 \mathrm{~g} \mathrm{~kg}^{-1}$, but it was significantly lower than other treatments (Table 4). The percentage of seed damage was influenced by the mortality of infested adults and the population growth of $R$. dominica on each treatment. The lower seed damage on giant bamboo leaves ash was caused by the high mortality of infested adults and lower hatched larvae, thus their feeding activity was lower than other treatments.

The viability of maize seed by $S$. zeamais was influenced by the number of larvae and adults which are actively damaged the stored products [31]. Larvae and adults feed on the seed embryo and endosperm, therefore the seeds unable to germinate. Newly hatched larvae was feed on the flour dust due to the results of adults attacked, while a certain larvae instar could enter the seed by boring the grain surface [7]. This holes causes the seed damage and reduce the germination potential or even un-germinated. Furthermore, it was revealed that the application of rice husk ash, tomaren indispron-P406, and cow feces to the seed which attacked by Sitotroga cerealella in the storage were able to keep the seed germination up to $90 \%$ for 3 months and $84.67 \%$ for 6 months [38].

Table 4. The percentage of seed damage on treated rice seeds by five types of inert dust

\begin{tabular}{lrl}
\hline Treatment & Seed damage (\%)* \\
\hline Untreated (Control) & $29.00 \pm 1.00 \mathrm{~h}$ \\
Rice husks $4 \mathrm{~g} \mathrm{~kg}^{-1}$ & $12.33 \pm 1.27 \mathrm{~cd}$ \\
Rice husks $8 \mathrm{~g} \mathrm{~kg}^{-1}$ & $11.00 \pm 1.00 \mathrm{bc}$ \\
Volcanic $4 \mathrm{~g} \mathrm{~kg}^{-1}$ & $19.67 \pm 1.53 \mathrm{~g}$ \\
Volcanic $8 \mathrm{~g} \mathrm{~kg}^{-1}$ & $15.67 \pm 2.08 \mathrm{ef}$ \\
Giant bamboo leaves 4 g kg-1 & $8.67 \pm 1.15 \mathrm{ab}$ \\
Giant bamboo leaves $8 \mathrm{~g} \mathrm{~kg}^{-1}$ & $6.67 \pm 3.06 \mathrm{a}$ \\
Corncobs $4 \mathrm{~g} \mathrm{~kg}^{-1}$ & $18.00 \pm 1.00 \mathrm{fg}$ \\
Corncobs $8 \mathrm{~g} \mathrm{~kg}^{-1}$ & $14.33 \pm 1.15 \mathrm{de}$ \\
Coconut shells $4 \mathrm{~g} \mathrm{~kg}^{-1}$ & $18.00 \pm 2.00 \mathrm{fg}$ \\
Coconut shells $8 \mathrm{~g} \mathrm{~kg}^{-1}$ & $15.33 \pm 2.00 \mathrm{def}$ \\
\hline Notes: & Mean \pm SD followed by different letters in the same column are significantly \\
different by Duncan's Multiple Range Test $(\alpha<0.05)$. &
\end{tabular}




\section{CONCLUSION}

The application of giant bamboo leaves ash and rice husks ash as inert dust at 4 and $8 \mathrm{~g} \mathrm{~kg}^{-1}$ was more effective to increase the adult mortality, inhibit insect population growth, and decrease the seed damage compared to volcanic, corncobs, and coconut shells ash at the same dose in stored rice seeds. In conclusion, these ashes were potentially used as a grain protectant against $R$. dominica in stored rice seeds.

\section{Acknowledgement}

The authors would like to thank Department of Plant Pests and Diseases, Faculty of Agriculture, University of Brawijaya for supporting this research.

\section{REFERENCES}

[1] Koehler, P.G., R.M. Pereira. 2012. Lesser grain borer, Rhyzopertha dominica (Coleoptera, Bostrichidae). University of Florida. Gainesville.

[2] Astuti, L.P., G. Mudjiono, S. Rasminah, B.T. Rahardjo. 2013. Influence of temperature and humidity on the population growth of Rhyzopertha dominica (F.) (Coleoptera: Bostrichidae) on milled rice. J. Entomol. 10(2). 86-94.

[3] Wilbur, D.A. 1971. Stored grain insects. In: Pfadt, R.E. (Ed). Fundamentals of applied entomology second edition. Macmillan Publishing. New York. 495-522.

[4] Anggara, A.W., Sudarmaji. 2009. Hama pascapanen padi dan pengendaliannya. Center for Rice Crops (Balai Besar Tanaman Padi). Subang.

[5] Wang, F., D.S. Jayas, N.D.G. White, P. Fields. Combined effect of carbon monoxide mixed with carbon dioxide in air on the mortality of stored-grain insects. J. Stored Prod. Res. 45(4). 247-253.

[6] Opit, G., P.J. Collins, G.J. Daglish. 2012. Resistance management. In: Hagstrum D.W., T.W. Phillips, G. Cuperus (Eds). Kansas State University. Manhattan. 143-156.

[7] Hill, D.S. 2002. Pests of stored foodstuffs and their control. Kluwer Academic Publishers. New York.

[8] Jeyaratnam, J. 1990. Acute pesticide poisoning: A major global health problem. World Heal Stat. Q. 43(3). 139-144.

[9] Ezechukwu, C.C., R. Szlatcheka. 2001. An usual source of poisoning. Niger. J. Clin. Pract. 4(1). 37-39.
[10] Ikpesu, T.O., A.B. Ariyo. 2013. Health implication of excessive use and abuse of pesticides by the rural dwellers in developing countries: the need for awareness. Greener J. Environ. Manag. Public Saf. 2(5). 180-188.

[11] Nwaubani, S.I., G.P. Opit, G.O. Otitodun, M.A. Adesida. 2014. Efficacy of two Nigeriaderived diatomaceous earths against Sitophilus oryzae (Coleoptera: Curculionidae) and Rhyzopertha dominica (Coleoptera: Bostrichidae) on wheat. J. Stored Prod. Res. 59. 9-16.

[12] Golob, P. 1997. Current status and future perspectives for inert dusts for control of stored product insects. J. Stored Prod. Res. 33(1). 69-79.

[13] Howard, R.W., C.D. Howard, S. Colquhoun. 1995. Ontogenetic and environmentally induced changes in cuticular hydrocarbons of Oryzaephilus surinamensis (Coleoptera: Cucujidae). Ann. Entomol. Soc. Am. 88(4). 485-495.

[14] Kusumastuti, E. 2012. Pemanfaatan abu vulkanik Gunung Merapi sebagai geopolimer (suatu polimer anorganik aluminosilikat). Jurnal MIPA. 35(1). 66-76.

[15] Madakson, PB, D.S. Yawas, A. Apasi. 2012. Characterization of coconut shell ash for potential utilization in metal matrix composites for automotive applications. Int. J. Eng. Sci. Technol. 4(3). 1190-1198.

[16] Okoronkwo, E.A., P.E. Imoisili, S.A. Olubayode, S.O.O Olusunle. 2016. Development of silica nanoparticle from corn cob ash. Adv. Nanoparticles. 5(2). 135139.

[17] Priyanto, A. 2015. Sintesis dan aplikasi silika dari abu daun bambu petung (Dendrocalamus asper (Schult. f.) Backer ex Heyne) untuk mengurangi kadar ammonium dan nitrat pada limbah cair tahu. Thesis. Faculty of Tarbiyah and Teaching, Walisongo State Islamic University. Semarang.

[18] Eliche-Quesada, D., M.A. Felipe-Sesé, J.A. López-Pérez, A. Infantes-Molina. 2017. Characterization and evaluation of rice husk ash and wood ash in sustainable clay matrix bricks. Ceram Int. 43(1). 463-475.

[19] Heinrichs, E.A., F.G. Medrano, H.R. Rapusas. 1985. Genetic evaluation for insect resistance in rice. International Rice Research Institute. Los Baños. 
[20] Astuti, L.P., M.B. Mario, T. Widjayanti. 2018. Preference, growth and development of Oryzaephilus surinamensis (L.) (Coleoptera: Silvanidae) on red, white and black rice in whole grain and flour form. J. Entomol. Res. 42(4). 461-468.

[21] Mahdi, S.H.A., M. Khalequzzaman. 2006. Toxicity studies of some inert dusts with the cowpea beetle, Callosobruchus maculatus (Fabricius) (Coleoptera: Bruchidae). J. Biol. Sci. 6(2). 402-407.

[22] Masiiwa, P. 2004. Evaluation of African diatomaceous earths (DEs) as potential maize grain protectants against the maize weevil (Sitophilus zeamais). Thesis. Department of Crop Science, Faculty of Agriculture, University of Zimbabwe. Harare.

[23] Yang, F.L., G.W. Liang, Y.J. Xu, Y.Y. Lu, L. Zeng. 2010. Diatomaceous earth enhances the toxicity of garlic, Allium sativum, essential oil against stored-product pests. J. Stored Prod. Res. 46(2). 118-123.

[24] Khakame, S.K., P. Likhayo, F.M. Olubayo, J.H. Nderitu. 2012. Effect of grain moisture content and storage time on efficacy of inert and botanical dusts for the control of Sitophilus zeamais in stored maize. J. Stored Prod. Postharvest Res. 3(10). 145-151.

[25] Abbott, W.S. 1925. A Method of computing the effectiveness of an insecticide. J. Econ. Entomol. 18(2). 265-267.

[26] Bashir, T. 2002. Reproduction of Rhyzopertha dominica (F.) (Coleoptera: Bostrichidae) on different host-grains. Pakistan J. Biol. Sci. 5(1). 91-93.

[27] Astuti, L.P., G. Mudjiono, S. Rasminah Ch., B.T. Rahardjo. 2013. Susceptibility of milled rice varieties to the lesser grain borer (Rhyzopertha dominica, F). J. Agric. Sci. 5(2). 145-149.

[28] Syafruddin, T. Miranda. 2015. Vigor benih beberapa varietas jagung pada media tanam tercemar hidrokarbon. J. Floratek. 10(1). 18-25.

[29] Adams, J.M., G.G.M. Schulten. 1978. Loss caused by insects, mites and microorganisms. In: Harris, K.L., C.L. Lindbland (Eds). Post-harvest grain loss assessment methods. American Association of Cereal Chemists. Madison. 83-95.

[30] Doumbia, M., B.G. Douan, K.E. Kwadjo, D.K. Kra, V. Martel, M. Dagnogo. 2014.
Effectiveness of diatomaceous earth for control of Sitophilus zeamais (Coleoptera: Curculionidae), Tribolium castaneum and Palorus subdepressus (Coleoptera: Tenebrionidae). J. Stored Prod. Res. 57. 1-5.

[31] Jean, W.G., N.E. Nchiwan, N. Dieudonné, S. Christopher, C. Adler. 2015. Efficacy of diatomaceous earth and wood ash for the control of Sitophilus zeamais in stored maize. J. Entomol. Zool. Stud. 3(5). 390-397.

[32] Athanassiou, C.G., N.G. Kavallieratos, L.P. Economou, C.B. Dimizas, B.J. Vayias, S. Tomanović, M. Milutinović. 2005. Persistence and efficacy of three diatomaceous earth formulations against Sitophilus oryzae (Coleoptera: Curculionidae) on wheat and barley. J. Econ. Entomol. 98(4). 1404-1412.

[33] Subramanyam, B., R. Roesli. 2000. Inert dusts. In: Subramanyam, B., D.W. Hagstrum (Eds). Alternatives to pesticides in storedproduct IPM. Springer Science+Business Media. New York. 321-80.

[34] Ibrahim, N.D., A. Audu, M.C. Dike, M. Lawal. 2012. Original article effect of raw diatomaceous earth and plant powders on Callosobruchus subinnotatus (Pic.) infesting stored bambara groundnut seeds. Sci. J. Pure Appl. Sci. 1(1). 9-16.

[35] Djojosumarto, P. 2008. Panduan lengkap pestisida \& aplikasinya. Agromedia Pustaka. Jakarta.

[36] Alexander, P., J.A. Kitchener, H.V.A. Briscoe. 1944. Inert dust insecticides: Part III. The effect of dusts on stored products pests other than Calandra granaria. Ann. Appl. Biol. 31(2). 156-159.

[37] Ebeling, W. 1971. Sorptive dusts for pest control. Annu. Rev. Entomol. 16(1). 123158.

[38] Rajasri, M., P.S. Rao, K.K.V.S. Meena. 2014. Inert dusts -Better alternatives for the management of angoumois grain moth, Sitotroga cerealella in stored rice. Int. J. Sci. Res. 3(10). 278-283. 